\title{
The New System of Contemporaneous Reserve Requirements
}

\author{
R. ALTON GILBERT and MICHAEL E. TREBING
}

T

筩 HE Board of Governors of the Federal Reserve System recently announced its decision to implement a version of contemporaneous reserve requirements (CRR) that will become effective in Februay 1984. This article describes both the regime of lagged reserve requirements (LRR) currently in effect and the new system of CRR, and explains why each feature of the new reserve accounting system was adopted.

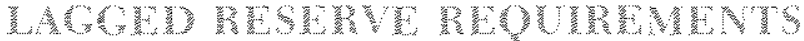

Under the current system of reserve acomuting, reserve maintenance periods - periods during which a depository institution's average daily reserves must equal or exceed its required reserves-cover seven days ending each Wednesday. An institution's required reserves for the curent reserve mantenance week are based on its average daily deposit liabilities in the computation period two weeks earlier, as illustrated in exhibit 1. Assets comted as reserves in the current maintenance week include the average daily vault cast held in the computation period two weeks earlier, plus average reserve balances held in the current maintenance period. A depository institution must keep its average reserves within 2 percent of its required reserves to avoid incurring a penalty for a deficiency or losing credit for holding excess reserves. ${ }^{1}$

\footnotetext{
A reserve deficiency up to 2 percent of required reserves in one mantenance week may be made up the next week without incurring a penalty. Excess reserves up to 2 percent of required reserves may be counted as part of reserves in the following week.
}

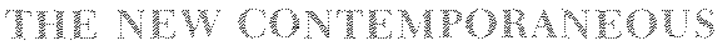

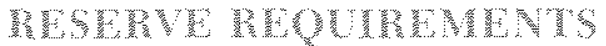

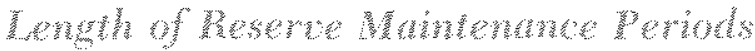

Reserve maintenance periods will be lengthened from one week to two weeks; they will cover 14 days ending every other Wednesday.

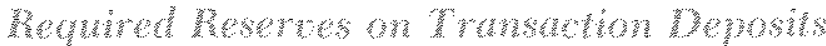

Under contemporaneous reserve accounting. there will be considerable overlap between the reserve compatation and maintenance periods for transaction deposits. Required reserves in the current 14-day maintenance period will be held against the average level of transaction deposit liabilities over 14 days end ing two days before the end of the current maintenance period (exhibit 1).

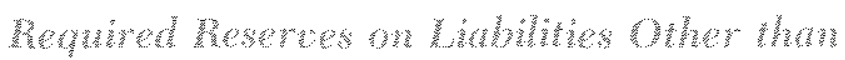

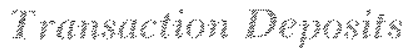

Required reserves against liabilities other than transaction deposits (nonpersonal time deposits and Eurodollar liabilities) will be based on average liabilities over 14 days ending 30 days before the end of the current maintenance period (exhibit 1).

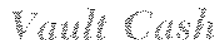

Vaull cash counted as reserves will continue to be lagged under CRR. Thus, a depository institution's 


\section{Exhibit 1}

\section{Timing of Lagged and Contemporaneous Reserve Accounting Systems}

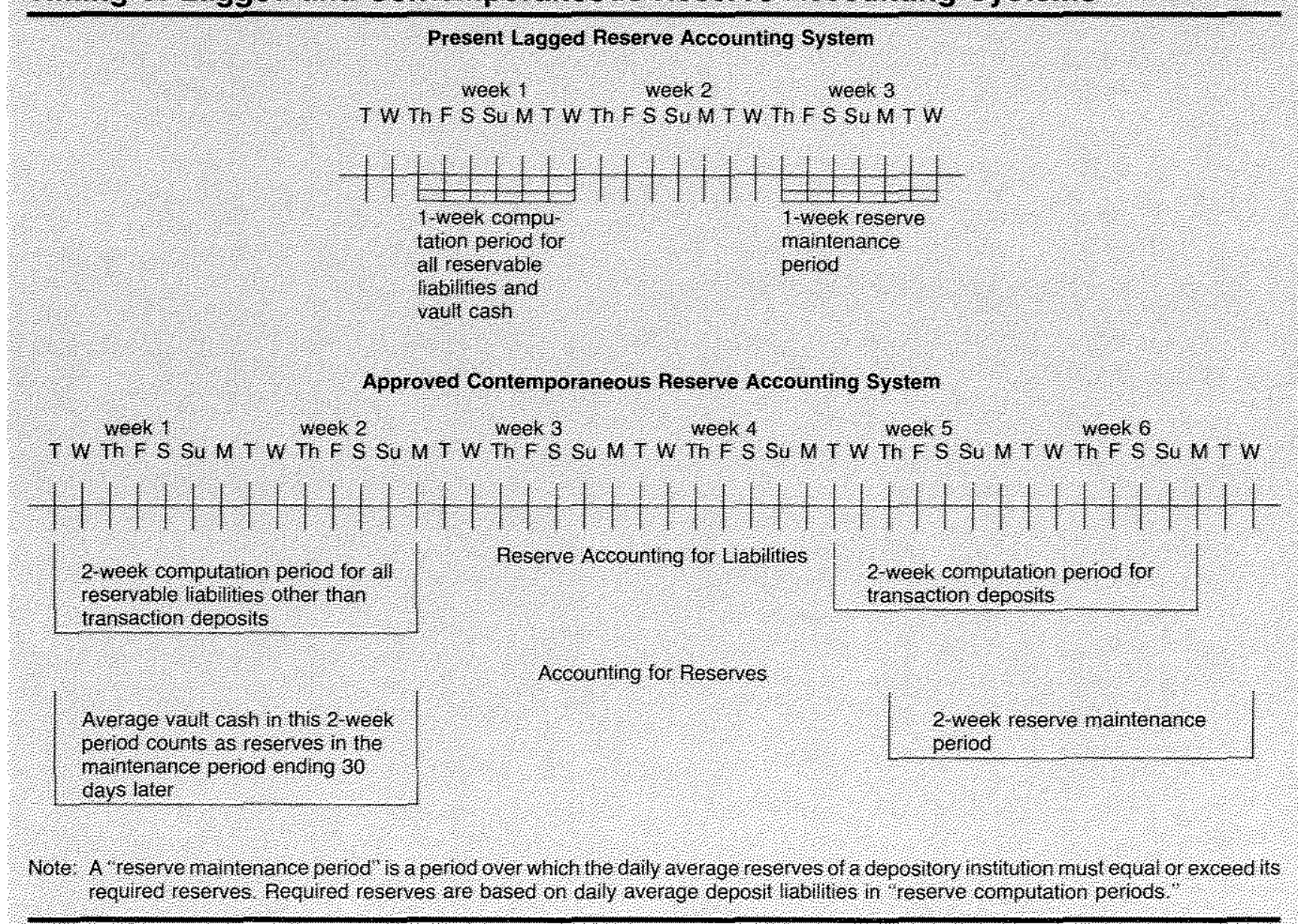

reserves in the current maintenance period will include average vault cash held in the 14 -day period ending 30 days before the end of the current maintenance period, plus its average daily reserve balances during the current maintenance period (exhibit 1).

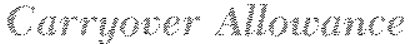

The carryover allowance specifies the amount of excess reserves in one maintenance period that a depository institution may use to meet its required reserves in the next maintenance period, or the amomt of a reserve deficiency that may be held in the following maintenance period without incurring a penalty

Each institution will have a minimum carryover allowance of $\$ 25,000$. During the first six months of
CRR, each depository institution will be allowed to carry over to the next maintenance period excess reserves or deficiencies up to 3 percent of required reserves, or $\$ 25,000$, whichever is larger. In the following six months, the allowable percentage carryover will be 2.5 percent. Thereafter, it will remain at 2 percent, with the $\$ 25,000$ minimm still in effect. This minimum carryover will exceed 2 percent of required reserves for institutions with required reserves below $\$ 1.25$ million

With two-week maintenance periods, a carryover allowance of 2 percent is effectively twice as large as a 2 percent carryover under one-week maintenance periods. To illustrate this, suppose an institution has information on its transaction deposits for each day of the computation period except the last day. Transac- 
tion deposits were $\$ 10$ million until the last day, when they rose to $\$ 12$ million. For simplicity, assume that the reserve requirement on transaction deposits is 10 percent. Since the institution does not know about the rise in transaction deposits on the last day, it holds average reserves of $\$ 1$ million during the maintenance period (assuming no required reserves on liabilities other than transaction deposits). If reserve computation periods and matintenance periods covered only seven days, average reserves of $\$ 1$ million would be 2.78 percent below required reserves of $\$ 1.0286 \mathrm{mil}-$ lion. With 14day maintenance periods, in contrast, the rise of transaction deposits to $\$ 12$ million on the last day of the computation period would make the average reserves of $\$ 1$ million only 1.41 percent below the average required reserves of $\$ 1.0143$ million.

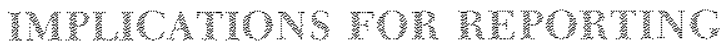

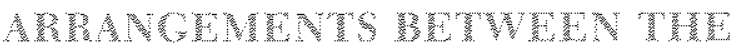

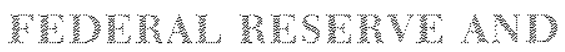

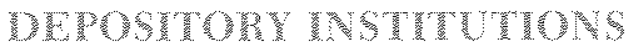

Under the current system of LRR, there is a oneweek gap between the end of the period over which a depository institution calculates its deposit liabilities and the beginning of the seven-day period over which it holds the required reserves. During that intermediate week, each depository institution informs the Federal Reserve of its deposit liabilities and vault cash; the Federal Reserve, in turn, informs each depository institution of its required reserve balances before the beginning of each maintenance period.

Under the plan for CRR, the Federal Reserve will notify a depository institution before the beginning of each two-week maintenance period how much reserves it is required to hold against liabilities other than transaction deposits and the amount of vault cash it may count as reserves. Each depository institution then must monitor its transaction deposits during the current computation period for those deposits and hold the appropriate amount of reserve balances. After each maintenance period, the Federal Reserve will determine whether each institution's reserves were adequate. $^{2}$

\footnotetext{
2The arrangements for determining compliance with reserve rem quirements are more complicated under the pass-through arrangement. Depository institutions that are not members of the Federal Reserve System may choose to hold their required reserve balances in their own reserve accomnts at Federal Reserve Banks, or designate other institutions to hold the required reserve balances for therm. Depository institutions that hold required reserve bal-
}

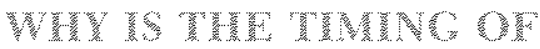

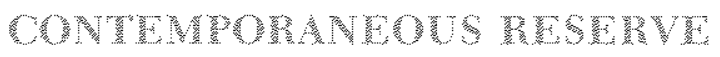

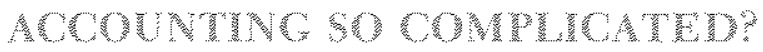

The timing of reserve accounting under the new system of CRR is designed to strengthen the relationship between money growth and reserve growth by creating a nearly contemporaneous link between transaction deposit liabilities and the required reserves against those deposits. This section explains why each feature of the new reserve accounting system was adopted, and the system's role in binding shortrun money growth more closely to the growth of total reserves of all depository institutions. ${ }^{3}$

\section{算}

It takes at least one day for banks to compile information on their deposit liabilities. The two days between the end of the reserve computation period for transaction deposit liabilities and the end of the maintenance period permits depository institutions to compile in. formation on their deposit liabilities and to make the final adjustments to their reserve balances for each maintenance period.

Since there is a two-day lag between the end of the period over which depository institutions will measure their deposit liabilities and the end of the period over which they will hold reserves, the new system of reserve accounting is not exactly a contemporaneous one. If maintenance periods had remained one week under the new regulations, required reserves would

ances for other institutions are called pass-through agents. Under LRR, a pass-through agent receives a report from the Federal Reserve before the beginuing of each settlement week on the required reserve balance of each institution for which it holds reserves. Under CRR, a pass-through agent will have to monitor the transaction deposits of the institutions for which it holds required reserves during each settlement period, and the Federal Reserve will determine after the fact whether the reserve balances held by the passthromgh agent were sufficient, given the liabilities of the depository institutions for which it holds reserve balances.

${ }^{3}$ This paper does not discuss the effects of adopting CRR on monetary control. Whether money growth is actually more stable after CRR goes into effect will depend, in part, on the weight given to short-run monetary control in the conduct of monetary policy. For a theoretical analysis of the significance of reserve accounting for monetary control, see Daniel $\mathrm{L}$. Thornton, "Simple Analytics of the Money Supply Process and Monetary Control," this Review (October 1982), pp. 22-39. The change in reserve accounting from LRR to CRR also has implications for reserve management by individual depository institutions, which are not discussed in this paper. See R. Alton Gilbert, "Lagged Reserve Requirements: Implications for Monetary Control and Bank Reserve Management," this Review (May 1980), pp. 7-20. 
have been predetermined by prior deposit creation for two-sevenths of each maintenance period. By making maintenance periods two weeks long, each period for measuring transaction deposits overlaps six-sevenths of the period for holding required reserves against them. Consequently, required reserves are predotermined for only one-seventh of each maintenance period.

Increasing reserve maintenance periods from one week to two weeks creates the potential for large gaps to develop between reserves and required reserves unless depository institutions adjust their reserves to anticipated levels of required reserves frequently throughout the maintenance period. If depository institutions wait until the end of each maintenance period to adjust their reserve positions, the Federal Reserve is faced with two choices: 1) to allow lange fluctuations in the federal funds rate near the end of maintenance periods (to force transaction deposits to the Fed's target levels), or 2 ) to adjust the supply of reserves to accommodate the levels of transaction deposits created by depository institutions. If the Federal Reserve chooses to keep total reserves on target, however, depository institutions will discover that they must keep their reserves close to the required reserves throughout each maintenance period, if they want to minimize their interest-rate risk.

\section{Tugged Acounting for Woult Cas}

Counting vault cash as reserves on a lagged basis facilitates the control of total reserves. The Federal Reserve does not know the amount of coin and currency held by depository institutions until these institutions flle reports on their deposit liabilities and reserve assets. If the vault cash held in the current maintenance period counted as reserves in the current period, the Federal Reserve's errors in estimating current vault cask would lead to errors in the amount of reserves the Fed supplied. With lagged accounting for vault cash, the Federal Reserve will know, at the beginning of each maintenance period, the exact amount of vault cash to count as reserves. ${ }^{4}$

\footnotetext{
Lagged accountirg for vanlt cash allows depository instifutions to increase (decrease) their resenes temporarily by depositing vault cash in (withdrawing vant cash from) their reserve accounts. Control of total reserves by the Federal Reserve could be adversely affected if deposifory institations adjust their reserve positions by deposieng and withdrawing valt cash. Coats finds little or no evidence, however, that commercial banks have used changes in their valt cash as a method of reserve adjustment. See Warren $L$. Coats, Jr. "Regulation D and the Vault Cash Game, Journal of Finance (June 1973), pp. 601-07.
}

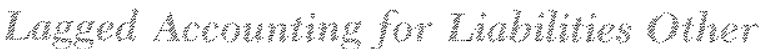

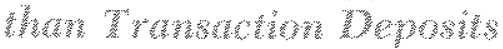

The reserve requirements on non-transaction deposit accounts would create potential problems for short-run monetary control if required reserves were based on the amount of those non wransaction liabilities in the current period. To determine the amount of reserves for the current period available to "support" transaction deposits, the Federal Reserve would have to estimate the required reserves on the nontransaction deposit liabilities. Errors in those estimates would create errors in supplying the desired amount of reserves available to support transaction deposits. With lagged accounting for non-transaction deposit liabilities, however, the Federal Reserve will know, at the beginning of each maintenance period, the required reserves on these deposits.

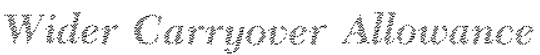

The purpose for widening the carryover allowance under CRR is to make reserve management easier for depository institutions. They may have difficulty from time to time calculating their transaction deposits quickly enough to determine exactly their required reserves by the end of the maintenance period. The carryover allowance permits discrepancies between their actual reserves and their required reserves in one maintenance period to be offset in the following period, within the limits described above. The maximum carryover allowance is initially set at 3 percent of required reserves, since difficulties in calculating required reserves on a contemporaneous basis are expected to be greatest during the first few months after CRR becomes effective.

Implications of the wider carryover allowance for the relationship between short-rm money growth and reserve growth depend on whether depository institu tions will have significant difficulty in estimating their required reserves, and how they will manage their reserve positions. Even if depository institutions can calculate their required reserves on a contemporaneous basis, they still might use the carryover allowance to avoid the costs involved in keeping their reserves equal to their required reserves. If depository institutions would use the carryover allowance to delay adjusting their reserves to required reserves, widening the carryover allowance will tend to weaken the short-run relationship between transaction deposits and reserves. 
In contrast, suppose that depository institutions will have to estimate their required reserves under CRR, because of incomplete information on their transaction deposits near the end of the computation periods for those deposits. In particular, suppose that by the end of each reserve maintenance period, which is every other Wednesday, each depository institution has information on its transaction deposits through the prior weekend, but lacks information on transaction accounts for Monday, the last day of the computation period for transaction deposits. Each institution estimates transaction deposits on that Monday as the level over the prior weekend. To avoid penalities on reserve deficiencies or the unprofitable holding of excess reserves, each depository institution would keep its reserves equal to its estimate of required reserves, and use the carryover allowance to accommodate differences between estimates of required reserves and final values. An institution that has an increase in its transaction deposits on the Monday before the end of a maintenance period will end up with deficient reserves; it will not know about the rise in transaction deposits on the last day of the computation period, but will lend to other institutions any increase in reserves that resulted from the unexpected deposit inflow. An institution that had a reduction in transaction deposits on the last day of the computation period will have excess reserves, since actual required reserves will be less than the estimated level, and any loss of reserves due to the unexpected deposit outflow will be replaced by borrowing reserves from other institutions.
Under these conditions, widening the carryover allowance need not have adverse effects on the moneyreserve growth relationship. Deviations of reserves from required reserves at individual institutions would not necessarily weaken the short-run money-reserve growth relationship, since those deviations would tend to be offsetting. The implications of the wider carryover allowance, therefore, will depend on whether it is wide enough to accommodate the errors that depository institutions make in estimating their required reserves on a contemporaneous basis, yet small enough to induce them to keep their reserves close to their estimates of required reserves.

\section{COMOLYIONS}

The Federal Reserve has adopted a new system of contemporaneous reserve accounting that will become effective in February 1984. The new system of reserve accounting is intended to strengthen the relationship between transaction deposit balances and the total reserves of depository institutions. The timing of reserve accounting under the new system appears to be complicated. Each feature, however, was adopted to facilitate short-run monetary control, while making allowance for the difficulties that depository institutions will have in measuring deposit liabilities and holding required reserves on a contemporaneous basis.

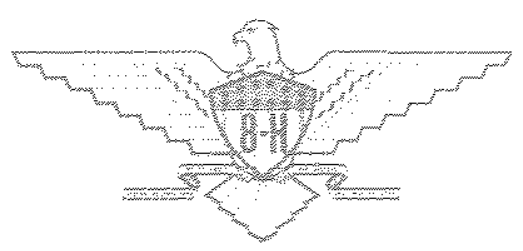

